\title{
TREHALOSE ACCUMULATION, INVERTASE ACTIVITY AND PHYSIOLOGICAL CHARACTERISTICS OF YEASTS ISOLATED FROM 24 H FERMENTATIVE CYCLES DURING THE PRODUCTION OF ARTISANAL BRAZILIAN CACHAÇA
}

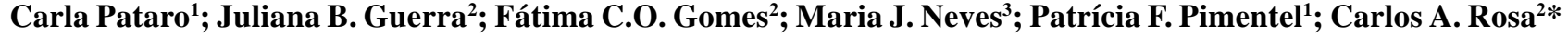 \\ ${ }^{1}$ Setor de Biotecnologia e Tecnologia Química, Fundação Centro Tecnológico de Minas Gerais (CETEC), Belo Horizonte, MG, \\ Brazil. ${ }^{2}$ Departamento de Microbiologia, Instituto de Ciências Biológicas, Universidade Federal de Minas Gerais, Belo \\ Horizonte, MG, Brazil. ${ }^{3}$ Comissão Nacional de Energia Nuclear (CNEN), Belo Horizonte, MG, Brazil.
}

Submitted: August 21, 2001; Returned to authors for corrections: January 09, 2002; Approved: July 26, 2002

\begin{abstract}
Trehalose accumulation, invertase activity and physiological characteristics of 86 yeast isolates from short fermentative cycles during the production of cachaça in three artisanal distilleries of the State of Minas Gerais were studied. Among these isolates, $70 \%$ were able to grow at temperatures between 40 and $42^{\circ} \mathrm{C}$. Only Saccharomyces cerevisiae isolates were able to grow over $40^{\circ} \mathrm{C}$. Lower temperatures $\left(<40^{\circ} \mathrm{C}\right)$ favoured the growth of yeasts such as Candida parapsilosis-like, C. maltosa-like, Kloeckera japonica, S. exiguus and $C$. bombicola-like. The isolates from all three distilleries were ethanol tolerant, produced invertase, and accumulate trehalose in the presence of glucose. The strains isolated from distillery A presented more resistance to ethanol (around $84.2 \%$ of the strains were able to grow in the presence of $12 \%$ ethanol) when compared to the ones from distilleries C and B (9.5\% and no strain, respectively). The strains of S. cerevisiae isolated from the three distilleries presented a higher capacity to produce invertase and accumulate trehalose in the presence of glucose. Based on the results of thermal and ethanol stress experiments, it was possible to identify strong relationship between intracellular trehalose accumulation and cell viability. The increase in cell viability was even more pronounced when the strains were subjected to a pre-treatment at sublethal temperatures.
\end{abstract}

Key words: Saccharomyces cerevisiae, cachaça, trehalose, invertase, fermentation.

\section{INTRODUCTION}

The production of many different alcolholic beverages involves spontaneous fermentations caused by microorganisms present in the raw materials and/or the equipments (10). Such a natural fermentation process takes place in the production of sugar cane cachaça (aguardente) in Minas Gerais State. Cachaça production in Minas Gerais amounts to approximatelly 210 milion liters per year, through the distillation of the fermented sugar cane must. This production occurs from May to December, during the sugar cane cropping period. One of the main peculiarity of the artisanal production of cachaça is the preparation of the starter ferment, which consists of the propagation of the fermentative microbiota through a mix of sugar cane juice with corn, rice and/or soya flour. The process occurs inside the fermentation vat and can last from 5 to 20 days, until the yeast population is sufficient to initiate the fermentative cycle. The fermentative cycle results in the consumption of the total sugar present in the sugar cane juice and occurs in a period that can vary between 18 to 48 hours. The yeast communities present in such fermentations are in constant succession, and the species present in the fresh sugar cane juice are constantly introduced in the microenvironment of the fermentation. Saccharomyces cerevisiae is the predominant species at the end of starter preparation and during the fermentative cycle $(14,18)$.

\footnotetext{
* Corresponding author. Mailing address: Departamento de Microbiologia, Instituto de Ciências Biológicas, Universidade Federal de Minas Gerais, Caixa Postal 486, Pampulha, Belo Horizonte, MG, Brasil. Fax: (+5531) 3499 2730; E-mail: carlrosa@ icb.ufmg.br.
} 
The physiological abilities of the yeast strains isolated from fermented must have a special relevance in understanding the mechanisms involved in must colonization, and determining the optimum conditions to maintain healthy fermentations (17). In S. cerevisiae, a strong correlation between trehalose content and stress resistence has been demonstrated in different strains, in a variety of growth conditions, during sublethal heat treatment and other stress conditions $(4,24)$. Some of the unique features of cachaça fermentation, namely a short fermentative cycle with the daily addition of sugar cane juice, a high ethanol concentration and a high fermentation temperature may be responsible for the selection of highly adapted yeast strains. In this work, yeasts isolated during $24 \mathrm{~h}$-fermentation cycles of three cachaça distilleries in the State of Minas Gerais were studied for their osmotolerance, ability to grow and ferment at high temperatures, alcohol tolerance, invertase activity, and trehalose accumulation under normal and stressful conditions.

\section{MATERIALS AND METHODS}

Eighty-six yeasts were isolated from three cachaça distilleries in State of Minas Gerais as described in Pataro et al. (18). The samplings were made at $4 \mathrm{~h}$ intervals during the $24 \mathrm{~h}$ fermentative cycle of cachaça production. The strains were characterized according to standard methods $(8,23)$, and identified by the keys of Barnett et al. (2) and Kurtzman and Fell (9).

The yeast isolates were grown on modified Sabouraud agar (D-glucose $2 \%$, peptone $1 \%$, yeast extract $0.5 \%$, and agar $2 \%$ ) at room temperatures for $24 \mathrm{~h}$, and $0.1 \mathrm{ml}$ of a suspension containing $1 \times 10^{7}$ cells was inoculated in $5 \mathrm{ml}$ of the following culture media: Sabouraud broth with 15, 20, 25, 40 and $50 \%$ of glucose to test osmotolerance; YM broth (yeast extract $0.3 \%$, malt extract $0.3 \%$, peptone $0.5 \%$ and glucose $1 \%$ ) with $8,10,12$ and $13 \mathrm{~g} / \mathrm{l}$ of ethanol (ethanol was added after sterilization and the tubes were covered with a parafilm to avoid ethanol evaporation); and in Sabouraud broth incubated in water bath at 35 to $43^{\circ} \mathrm{C}$ to evaluate the maximum growth temperature. Osmotolerance and ethanol resistance were determined at room temperature $\left(25 \pm 3^{\circ} \mathrm{C}\right)$. Yeast growth was evaluated from the turbidity of the liquid medium. Fermentation at high temperature was tested in Durham tubes containing fermentation basal medium (peptone $0.75 \%$, yeast extract $0.45 \%$ and $2 \%$ glucose) and incubated at temperatures from 37 to $45^{\circ} \mathrm{C}$ at one degree intervals. The maximum temperature of fermentation was taken to be the highest temperature at which gas production occurred after 24 hours of incubation (13).

The invertase activity was measured by the dinitrosalicilic (DNS) colorimetric test as described in Ekunsanmi and Odunfa (5). Each yeast was grown on Sabouraud agar for 48 hours, the cells were diluted in sterile water, washed by centrifugation, and $0.1 \mathrm{~g}$ wet weight of each was resuspended in $10 \mathrm{ml}$ of acetate buffer, $\mathrm{pH}$ 5.0. One mililiter of each cell suspension was added to $2 \mathrm{ml}$ of $4 \%$ sucrose solution in the same buffer and incubated for $5 \mathrm{~min}$. at $30^{\circ} \mathrm{C}$. One unit of invertase activity was defined as the amount of enzyme which liberated one $\mu \mathrm{mol} / \mathrm{min}$ of reducing sugars under these conditions.

For trehalose accumulation tests, $S$. cerevisiae cells were grown in $50 \mathrm{ml}$ YEPD (1\% yeast extract, $2 \%$ peptone and $2 \% \mathrm{D}$ glucose) at room temperature for approximately $24 \mathrm{~h}$ until glucose was consumed. The cells were filtered through $0.45 \mu \mathrm{M}$ Millipore membranes and the cell pellet was scraped off the membranes and immediately frozen in a vessel with liquid nitrogen. Trehalose was determined enzymatically with a trehalase preparation extracted from Humicola grisea essentially as described by Neves et al. $(15,16)$, and glucose liberated was assayed by the glucose-oxidase method (7). A trehalase unit was defined as the amount of enzyme which released one mmol glucose per min under the assay conditions.

Two strains of Saccharomyces cerevisiae were selected from each studied distillery, on the basis of the highest and lowest trehalose content, to be subjected to the thermal and ethanol stress tests. The heat shock test and ethanol stress test were performed as described in Ribeiro et al. (19). For heat shock experiments, the cultures harvested in the presence of glucose were aseptically divided in two aliquots. The first aliquot was given a $50^{\circ} \mathrm{C}$ treatment in a water bath for $8 \mathrm{~min}$. The second portion was first preconditioned at $40^{\circ} \mathrm{C}$ for $60 \mathrm{~min}$ and then immediately exposed to the $50^{\circ} \mathrm{C}$ heat shock for $8 \mathrm{~min}$. For ethanol stress experiments, an aliquot containing $100 \mathrm{mg}$ of cells (dry wt) in stationary phase was transferred to a sterile erlenmeyer flask and absolute ethanol was added to a final concentration of $10 \%$ (v/v) - modified from Mansure et al. (12) - and incubated at $28^{\circ} \mathrm{C}$ at $160 \mathrm{rpm}$ for $24 \mathrm{~h}$. Trehalose accumulation was measured as described previously. Samples for trehalose measurements and cell viability were taken just before and immediately after the treatments for ethanol stress and heat shock. Cell suspensions were appropriately diluted, and spread onto plates containing YEPD agar in triplicate. Tolerance to each treatment was expressed as the percentage of cell survival calculated from the difference in colony forming units (CFU) before and after the treatment.

\section{RESULTS AND DISCUSSION}

Most of the isolates $(90.7 \%)$ were able to grow in the presence of $40 \%$ glucose, but none were able to grow in 50\% glucose media. The yeasts that were not able to grow in $40 \%$ glucose were isolated only in distillery $\mathrm{B}$ and correspond to the following species: C. maltosa-like, C. parapsilosis-like, $C$. rugopelliculosa, C. azyma and K. japonica. Table 1 presents the results obtained from the physiological characterization tests. Most of the strains from distilleries A and B were able to grow at temperatures between 40 and $42^{\circ} \mathrm{C}$ but only $18.4 \%$ (distillery A) and $25.9 \%$ (distillery B) were able to grow at temperatures under $40^{\circ} \mathrm{C}$, representing mainly non-Saccharomyces yeast 
Table 1. Physiological characteristics of yeast isolated during the fermentative cycle (24 hours) in cachaça distilleries A, B and C.

\begin{tabular}{|c|c|c|c|c|c|c|c|}
\hline $\begin{array}{l}\text { Time }^{\mathrm{a}} \\
\text { (h) }\end{array}$ & $\begin{array}{c}\text { Species/strains } \\
\text { (UFMG97 A) }\end{array}$ & $\begin{array}{c}\log ^{\mathrm{b}} \\
\text { (cell numbers) }\end{array}$ & $\mathrm{MGT}^{\mathrm{c}}$ & $\mathrm{MFT}^{\mathrm{d}}$ & $\begin{array}{c}\text { Ethanol tolerance } \\
\text { (\%etanol) }\end{array}$ & $\begin{array}{c}\text { Invertase } \\
\text { production }^{\mathrm{e}}\end{array}$ & $\begin{array}{c}\text { Trehalose } \\
\text { accumulation }\end{array}$ \\
\hline \multirow{7}{*}{ T0 } & Distillery A & & & & & & \\
\hline & 1607-Saccharomyces cerevisiae & 9.23 & 39 & 43 & 12 & $60.0 \pm 2.47^{\mathrm{g}}$ & $47.5 \pm 0.02$ \\
\hline & 1608-S. cerevisiae & 7.6 & 41 & 43 & 12 & $20.0 \pm 0.70$ & $44.9 \pm 0.11$ \\
\hline & 1609-C. bombicola-like $\mathrm{h}^{\mathrm{h}}$ & 8.2 & 40 & 43 & 12 & $58.6 \pm 1.77$ & $67.9 \pm 0.01$ \\
\hline & 1610-S. cerevisiae & 9.11 & 39 & 43 & 12 & $77.2 \pm 0.00$ & $55.4 \pm 0.01$ \\
\hline & $1611-S$. cerevisiae & 8.64 & 41 & 45 & 12 & $40.7 \pm 0.14$ & $59.6 \pm 0.01$ \\
\hline & 1612- S. cerevisiae gly+ & 7.57 & 41 & 45 & 12 & $27.2 \pm 0.51$ & $57.1 \pm 0.05$ \\
\hline \multirow{6}{*}{$\mathrm{T} 1$} & 1613-S. cerevisiae & 8.08 & 41 & 43 & 12 & $44.8 \pm 0.42$ & $67.7 \pm 0.03$ \\
\hline & 1614-S. cerevisiae & 6.52 & 41 & 45 & 12 & $26.4 \pm 1.70$ & $8.6 \pm 0.03$ \\
\hline & 1615-C. bombicola- like & 7.4 & 40 & 45 & 12 & $62.0 \pm 0.92$ & $32.2 \pm 0.01$ \\
\hline & 1616-S. cerevisiae & 8.11 & 41 & 43 & 12 & $49.2 \pm 0.28$ & $55.6 \pm 0.10$ \\
\hline & 1617- S. cerevisiae gly+ & 7.61 & 41 & 45 & 12 & $43.4 \pm 0.14$ & $5.8 \pm 0.51$ \\
\hline & 1618-S. cerevisiae & 6.23 & 41 & 45 & 12 & $3.6 \pm 1.05$ & $27.7 \pm 0.25$ \\
\hline \multirow{6}{*}{$\mathrm{T} 2$} & 1619-S. cerevisiae & 8.20 & 41 & 45 & 12 & $69.2 \pm 1.30$ & $49.2 \pm 0.04$ \\
\hline & 1620-S. cerevisiae & 6.70 & 41 & 41 & 12 & $46.2 \pm 2.61$ & $15.6 \pm 0.33$ \\
\hline & 1621-C. bombicola-like & 7.30 & 40 & 45 & 12 & $52.0 \pm 0.84$ & $29.6 \pm 0.10$ \\
\hline & 1622- S. cerevisiae & 8.18 & 39 & 41 & 12 & $73.2 \pm 0.28$ & $20.7 \pm 0.01$ \\
\hline & 1623-S. cerevisiae & 7.64 & 41 & 45 & 12 & $62.0 \pm 1.20$ & $30.4 \pm 0.15$ \\
\hline & 1624- S. cerevisiae & 6.36 & 40 & 45 & 8 & $18.6 \pm 1.90$ & $43.7 \pm 0.11$ \\
\hline \multirow{6}{*}{$\mathrm{T} 3$} & 1626- S. cerevisiae & 8.41 & 39 & 40 & 12 & $69.2 \pm 1.76$ & $60.0 \pm 0.12$ \\
\hline & 1627- S. cerevisiae sal+ & 6.36 & 39 & 45 & 12 & $71.2 \pm 0.07$ & $45.3 \pm 0.02$ \\
\hline & 1628-C. bombicola- like & 7.52 & 39 & 42 & 12 & $69.2 \pm 0.77$ & $63.9 \pm 0.75$ \\
\hline & 1629- S. cerevisiae gly+ & 8.15 & 39 & 42 & 12 & $52.0 \pm 0.54$ & $64.4 \pm 0.01$ \\
\hline & 1630- $S$. cerevisiae sal+ & 7.54 & 41 & 45 & 10 & $15.4 \pm 0.85$ & $50.5 \pm 0.35$ \\
\hline & $1631-S$. cerevisiae sal+ & 6.30 & 40 & 45 & 12 & $11.4 \pm$ & $66.5 \pm 0.21$ \\
\hline \multirow{5}{*}{$\mathrm{T} 4$} & 1632-S. cerevisiae sal+ & 7.46 & 39 & 41 & 12 & $77.2 \pm 0.30$ & $46.3 \pm 0.51$ \\
\hline & 1633-S. cerevisiae sal+ & 5.48 & 39 & 42 & 12 & $17.7 \pm 1.41$ & $26.1 \pm 0.01$ \\
\hline & 1634- S. cerevisiae sal+ & 7.32 & 41 & 42 & 12 & $57.0 \pm 1.34$ & $8.2 \pm 0.01$ \\
\hline & 1635- S. cerevisiae gly+ & 6.89 & 39 & 45 & 8 & $45.3 \pm 0.35$ & $7.6 \pm 0.20$ \\
\hline & 1636- $S$. cerevisiae sal+ & 6.36 & 41 & 45 & 12 & $15.0 \pm 1.48$ & $3.0 \pm 0.12$ \\
\hline \multirow{4}{*}{ T5 } & 1637-S. cerevisiae gly+ & 7.20 & 39 & 45 & 12 & $62.0 \pm 1.83$ & $2.1 \pm 0.01$ \\
\hline & 1638-C. bombicola- like & 6.43 & 39 & 45 & 12 & $69.2 \pm 1.83$ & $2.4 \pm 0.15$ \\
\hline & 1639- $S$. cerevisiae sal+ & 7.11 & 39 & 42 & 12 & $71.2 \pm 1.69$ & $2.6 \pm 0.02$ \\
\hline & 1640- $S$. cerevisiae sal+ & 6.60 & 41 & 45 & 8 & $14.2 \pm 0.42$ & $3.2 \pm 0.15$ \\
\hline \multirow{5}{*}{ T6 } & 1641-S. cerevisiae & 7.11 & 39 & 42 & 12 & $57.0 \pm 0.28$ & $0.35 \pm 0.01$ \\
\hline & 1642-S. cerevisiae & 6.11 & 39 & 45 & 8 & $21.2 \pm 0.78$ & $1.4 \pm 0.10$ \\
\hline & 1643-S. cerevisiae & 7.04 & 39 & 43 & 12 & $31.9 \pm 0.92$ & $1.7 \pm 0.01$ \\
\hline & 1644-S. cerevisiae & 6.36 & 39 & 45 & 12 & $60.0 \pm 1.2$ & $8.5 \pm 0.00$ \\
\hline & 1645 S. cerevisiae & 5.48 & 39 & 45 & 10 & $5.3 \pm 0.77$ & $1.8 \pm 0.01$ \\
\hline \multirow{6}{*}{ T0 } & Distillery B & & & & & & \\
\hline & 1661-S. cerevisiae & 7.41 & 41 & 42 & 10 & $28.7 \pm 0.70$ & $2.2 \pm 0.01$ \\
\hline & 1662- C. maltosa- like & 5.48 & 40 & 40 & 6 & $0.8 \pm 1.15$ & $0.4 \pm 0.01$ \\
\hline & 1663-S. cerevisiae & 7.30 & 39 & 42 & 10 & $19.1 \pm 0.00$ & $0.0 \pm 0.00$ \\
\hline & 1665-C. parapsilosis -like & 5.48 & 40 & 40 & 6 & $0.9 \pm 0.03$ & $0.0 \pm 0.00$ \\
\hline & 1666- C. rugopelliculosa & 5.48 & 40 & 42 & 6 & $1.3 \pm 1.15$ & $0.3 \pm 0.01$ \\
\hline
\end{tabular}


Table 1. continuation...

\begin{tabular}{|c|c|c|c|c|c|c|c|}
\hline \multirow{6}{*}{$\mathrm{T} 1$} & 1667-S. cerevisiae & 8.53 & 42 & 45 & 8 & $60.2 \pm 1.13$ & $0.7 \pm 0.02$ \\
\hline & 1668-C. guilliermondii & 6.48 & 37 & 40 & 6 & $2.1 \pm 0.00$ & $5.3 \pm 0.04$ \\
\hline & 1669-S. exiguus & 8.76 & 40 & 43 & 8 & $52.0 \pm 0.70$ & $15.4 \pm 0.03$ \\
\hline & 1670- C. azyma & 6.48 & 41 & 45 & 8 & $38.6 \pm 1.34$ & $0.0 \pm 0.00$ \\
\hline & $1671-S$. cerevisiae & 5.48 & 40 & 42 & 8 & $17.0 \pm 1.41$ & $0.0 \pm 0.00$ \\
\hline & 1672-C. azyma & 4.78 & 37 & 40 & 6 & $1.0 \pm 0.56$ & $0.0 \pm 0.00$ \\
\hline \multirow{3}{*}{$\mathrm{T} 2$} & 1673-S. cerevisiae ma-tr- & 8.72 & 41 & 45 & 8 & $25.3 \pm 1.49$ & $10.0 \pm 0.33$ \\
\hline & 1674-S. cerevisiae & 8.53 & 41 & 42 & 8 & $17.5 \pm 1.83$ & $5.3 \pm 0.02$ \\
\hline & 1675-C. parapsilosis- like & 4.48 & 37 & 40 & 6 & $1.1 \pm 1.41$ & $0.8 \pm 0.15$ \\
\hline \multirow{5}{*}{$\mathrm{T} 3$} & 1656-S. cerevisiae & 9.04 & 42 & 41 & 10 & $17.6 \pm 0.85$ & $7.8 \pm 0.22$ \\
\hline & 1657- $S$. cerevisiae ma- & 8.98 & 42 & 45 & 10 & $28.7 \pm 0.65$ & $5.3 \pm 0.01$ \\
\hline & 1658-S. cerevisiae tr- & 5.48 & 41 & 45 & 10 & $26.4 \pm 0.22$ & $0.3 \pm 0.01$ \\
\hline & 1659- C. maltosa- like & 4.48 & 37 & 40 & 6 & $5.0 \pm 1.27$ & $0.2 \pm 0.00$ \\
\hline & 1660-C. maltosa- like & 4.48 & 37 & 40 & 6 & $7.1 \pm 0.63$ & $20.7 \pm 0.01$ \\
\hline \multirow{4}{*}{$\mathrm{T} 4$} & 1676-S. cerevisiae & 9.30 & 41 & 43 & 8 & $73.2 \pm 2.12$ & $9.7 \pm 0.11$ \\
\hline & 1677- $S$. cerevisiae ma- & 9.30 & 40 & 42 & 10 & $31.9 \pm 1.87$ & $0.3 \pm 0.01$ \\
\hline & 1678-K. japonica & 4.78 & 39 & 37 & 6 & $0.8 \pm 0.42$ & $0.6 \pm 0.01$ \\
\hline & 1680- $S$. cerevisiae gly+ & 9.18 & 40 & 45 & 8 & $46.2 \pm 1.34$ & $10.3 \pm 0.03$ \\
\hline $\mathrm{T} 5$ & $1681-S$. cerevisiae gly+ & 9.41 & 41 & 45 & 10 & $21.0 \pm 0.43$ & $25.8 \pm 0.88$ \\
\hline \multirow{3}{*}{ T6 } & 1682-S. cerevisiae ra- & 9.26 & 41 & 45 & 8 & $26.9 \pm 1.48$ & $9.5 \pm 0.01$ \\
\hline & 1683-S. cerevisiae & 9.89 & 41 & 43 & 8 & $24.6 \pm 0.64$ & $15.8 \pm 0.27$ \\
\hline & 1684- $S$. cerevisiae & 5.48 & 42 & 43 & 8 & $49.2 \pm 0.99$ & $5.2 \pm 0.31$ \\
\hline \multirow{5}{*}{ T0 } & Distillery $\mathbf{C}$ & & & & & & \\
\hline & 1685-S. kluyveri & 8.15 & 41 & 43 & 8 & $40.7 \pm 0.92$ & $7.3 \pm 0.02$ \\
\hline & 1686- $S$. cerevisiae $\mathrm{rb}+\mathrm{gly}+$ & 8.90 & 41 & 45 & 8 & $27.2 \pm 0.65$ & $10.0 \pm 0.31$ \\
\hline & 1687- $S$. cerevisiae $\mathrm{rb}+\mathrm{gly}+$ & 7.65 & 41 & 45 & 8 & $31.9 \pm 0.76$ & $14.1 \pm 0.20$ \\
\hline & 1688- $S$. cerevisiae $\mathrm{rb}+\mathrm{gly}+$ & 7.85 & 41 & 45 & 8 & $21.7 \pm 0.77$ & $4.8 \pm 0.01$ \\
\hline \multirow{4}{*}{$\mathrm{T} 1$} & 1689- $S$. cerevisiae $\mathrm{rb}+\mathrm{gly}+$ & 7.48 & 41 & 45 & 8 & $38.6 \pm 2.26$ & $13.1 \pm 0.23$ \\
\hline & $1690-S$. cerevisiae $\mathrm{rb}+\mathrm{gly}+$ & 7.70 & 41 & 45 & 8 & $24.6 \pm 0.14$ & $5.4 \pm 0.22$ \\
\hline & 1691- S. cerevisiae $\mathrm{rb}+\mathrm{gly}+$ & 7.54 & 41 & 45 & 8 & $47.8 \pm 0.35$ & $21.5 \pm 0.02$ \\
\hline & 1692- S. cerevisiae $\mathrm{rb}+\mathrm{gly}+$ & 7.72 & 41 & 45 & 10 & $19.1 \pm 1.98$ & $21.9 \pm 1.01$ \\
\hline \multirow{3}{*}{$\mathrm{T} 2$} & 1694- $S$. cerevisiae $\mathrm{rb}+\mathrm{gly}+$ & 7.46 & 42 & 45 & 8 & $29.3 \pm 0.65$ & $25.2 \pm 1.01$ \\
\hline & 1695- $S$. cerevisiae $\mathrm{rb}+\mathrm{gly}+$ & 7.82 & 41 & 45 & 8 & $9.5 \pm 1.70$ & $28.6 \pm 0.98$ \\
\hline & 1696- S. cerevisiae $\mathrm{rb}+\mathrm{gly}+$ & 7.86 & 41 & 42 & 10 & $60.2 \pm 1.70$ & $24.3 \pm 1.70$ \\
\hline \multirow{5}{*}{ T3 } & 1697- S. cerevisiae ra+tr- & 8.32 & 41 & 45 & 8 & $32.8 \pm 0.28$ & $19.4 \pm 1.21$ \\
\hline & 1698-S. cerevisiae ra+tr- & 9.04 & 40 & 43 & 8 & $22.4 \pm 0.42$ & $9.1 \pm 1.31$ \\
\hline & 1699- S. cerevisiae tr-gly+ & 8.36 & 41 & 42 & 10 & $42.9 \pm 0.21$ & $10.2 \pm 0.21$ \\
\hline & 1700-S. cerevisiae tr-gly+ & 9.40 & 42 & 45 & 8 & $31.9 \pm 1.90$ & $19.6 \pm 0.97$ \\
\hline & $1701-S$. cerevisiae tr-gly+ & 6.78 & 40 & 42 & 8 & $26.9 \pm 0.07$ & $4.2 \pm 0.21$ \\
\hline \multirow{4}{*}{$\mathrm{T} 4$} & 1702-S. cerevisiae tr-gly+ & 8.70 & 41 & 45 & 8 & $18.3 \pm 1.90$ & $22.6 \pm 0.04$ \\
\hline & 1703-S. cerevisiae tr-gly+ & 9.48 & 42 & 45 & 12 & $19.0 \pm 1.34$ & $9.1 \pm 0.01$ \\
\hline & 1704-S. cerevisiae tr-gly+ & 8.70 & 42 & 45 & 12 & $44.8 \pm 1.69$ & $12.2 \pm 0.02$ \\
\hline & $1705-S$. cerevisiae tr-gly+ & 9.48 & 41 & 42 & 8 & $45.3 \pm 1.20$ & $7.4 \pm 0.12$ \\
\hline
\end{tabular}

a-T0-addition of juice; T1-4hours, T2-8hours, T3-12hours, T4-16hours, T5-20hours, T6-24hours after addition of juice; b- log number of cells; c- MGT- Maximum growth temperature; $\mathbf{d}$ - MFT- Maximum fermentation temperature; $\mathbf{e}$ - Invertase activity was expressed in $\mu \mathrm{mol}$ reducing sugar $/ \mathrm{mg}$ cell $/ \mathrm{min}$. at $30^{\circ} \mathrm{C} ; \mathbf{f}-$ Trehalose accumulation was expressed in $\mu \mathrm{mol}$ glucose/g wet weight; g- Mean \pm standard error; $\mathbf{h}$ - Probable new yeast species physiologically similar to the species indicated. 
strains. The maximum fermentation temperature was normally greater than the maximum growth temperature. The highest value for fermentation was $45^{\circ} \mathrm{C}$. Most of the isolates from distillery A (84.2\%) grew in the presence of $12 \%$ ethanol whereas in distillery C only $9.5 \%$ from the isolates were able to grow in that ethanol concentration. In contrast, none of the distillery B isolates could grow in the presence of $12 \%$ ethanol. The cachaça fermentation microenvironment therefore appeared to select in favour of osmotolerant and ethanol resistent yeasts. The nonSaccharomyces yeasts that were unable to grow at high sugar and ethanol concentrations were similar to those isolated from sugar cane plantation soils by Corrêa (3). These data suggest that the non-Saccharomyces species are allochthonous members of the fermentative process, and these yeasts can be introduced daily with the addition of sugar cane juice. However, they disappear in the early phases of the fermentative cycle, being supplanted by $S$. cerevisiae. The majority of isolates had a maximum growth temperature of $40^{\circ} \mathrm{C}$. The average temperature of cachaça fermentations in Minas Gerais is $c a .30^{\circ} \mathrm{C}$, reaching as much as $42^{\circ} \mathrm{C}$ in the hottest regions of the state. Consequently, the presence of the thermotolerant strains in this environment is fundamental to the progress of the fermentative process.

The capacity to produce invertase (Table 1) was greatest in S. cerevisiae, with a maximum activity of $77.2 \mu$ mol reducing sugar $/ \mathrm{mg} \mathrm{cell} / \mathrm{min}$. The lowest invertase activity value $(0.8 \mu \mathrm{mol}$ reducing sugar $/ \mathrm{mg}$ cell $/ \mathrm{min}$.) was detected in a C. maltosa-like strain and a K. japonica strain. Our S. cerevisiae isolates showed greater invertase activity than that of a strain of $S$. cerevisiae isolated from the cassava tuber by Ekunsanmi and Odunfa (5), which had an invertase activity of $30.4 \mathrm{mmol}$ reducing sugar/ $\mathrm{mg}$ cell/min. Pataro et al. (17) isolated $S$. cerevisiae strains in other cachaça fermentations with an invertase activity greater than $100 \mu \mathrm{mol}$ reducing sugar $/ \mathrm{mg}$ cell/min. The daily addition, to the fermentation vats, of sugar cane juice with aproximatelly $16 \%$ sugar makes this environment selective for yeast that are efficient in the conversion of non-reducing sugars.
Most of the S. cerevisiae strains exhibited a great capacity to accumulate trehalose during the stationary growth phase (Table 1). S. cerevisiae strains from Distillery A had the highests levels of trehalose accumulation compared to those from distilleries B and C. Yeasts colonizing the fermentation microenvironment of artisanal cachaça production are always under thermal, osmotic and ethanol stress. Recently, it has been shown that intracellular trehalose levels can determine survival potential of yeasts in extreme environmental conditions $(1,15)$. Trehalose affords protection against stress in vitro and in vivo when cells are in stationary state or under stress (22). Many Saccharomyces strains exhibit a strong connection between trehalose accumulation and resistence to stress $(5,6,11,20)$. Around $40 \%$ of the isolated strains accumulated more than 40 mmol glucose/g wet weight in the stationary growth state. This trehalose accumulation capacity may be involved in the survival of strains in cachaça fermentation environments.

Tables 2 and 3 show the intracelular trehalose accumulation values and the viability of the $S$. cerevisiae strains under thermal and ethanol stress, respectively. The strains studied showed significant levels of trehalose accumulation when shifted to a preconditioning treatment at $40^{\circ} \mathrm{C}$ for $60 \mathrm{~min}$. A strong relationship between high viability and high trehalose accumulation was observed for all strains tested, specially when shifted to a sublethal temperature preconditioning treatment. Yeast strains submitted to an initial heat shock at $50^{\circ} \mathrm{C}$ for $8 \mathrm{~min}$. showed little resistence to severe heat shock and a very low trehalose level. All the yeast tested showed low viability when transferred directly from $28^{\circ} \mathrm{C}$ to $50^{\circ} \mathrm{C}$ for $8 \mathrm{~min}$ (Table 2). Hottiger et al. (6) reported that a temperature change from 27 to $40^{\circ} \mathrm{C}$ in growing cells of $S$. cerevisiae caused a trehalose accumulation from $0.01 \mathrm{~g} \mathrm{~g}^{-1}$ protein to $1 \mathrm{~g} \mathrm{~g}^{-1}$ protein over a period of $60 \mathrm{~min}$. Also a six-fold increase of intracellular trehalose concentration was found by Lewis et al. (11) when S. cerevisiae cells were exposed to a heat shock of $37^{\circ} \mathrm{C}$ lasting $45 \mathrm{~min}$. The strong relationship between the trehalose accumulation and strain

Table 2. Intracellular trehalose accumulation and cell viability of Saccharomyces cerevisiae strains submitted to heat stress.

\begin{tabular}{|c|c|c|c|c|c|c|}
\hline \multirow{2}{*}{$\begin{array}{c}\text { Strains } \\
\text { S. cerevisiae }\end{array}$} & \multicolumn{3}{|c|}{$\mu \mathrm{mol}$ de glucose/g wet weight } & \multicolumn{3}{|c|}{ Cell viability $^{\mathrm{d}}$} \\
\hline & Control $^{\mathrm{a}}$ & Pre-treatment ${ }^{b}$ & Heat shock ${ }^{\mathrm{c}}$ & Control & Pre-treatment ${ }^{\mathrm{e}}$ & Heat shock ${ }^{\mathrm{f}}$ \\
\hline UFMG-A1613 & $2.07 \pm 0.88^{\mathrm{g}}$ & $84.04 \pm 1.75$ & $10.28 \pm 0.29$ & $75.0 \pm 0.54$ & $0.63 \pm 0.26(0.84)$ & $0.97 \pm 0.20(1.29)^{\mathrm{h}}$ \\
\hline UFM & $1.78 \pm 0.20$ & 61 & & 55 & $1.40 \pm 0.0$ & $71(5.55)$ \\
\hline UFM & \pm 0.00 & & & & $0.095 \pm 0$ & $0.0)$ \\
\hline UFI & 1. & 34 & 15 . & 31.5 & $1.30 \pm 0$. & 12) \\
\hline UFM & $2.50 \pm 0.22$ & 87.6 & $19.61=$ & $1.0=$ & $0.70 \pm 0.0$ & $0.99 \pm$ \\
\hline UFMG-A1701 & $0.21 \pm 0.00$ & $47.28 \pm 2.60$ & $3.10 \pm 0.66$ & $1.0 \pm 0.01$ & $0.07 \pm 0.00(7.0)$ & $0.087 \pm 0.00$ \\
\hline
\end{tabular}

a- Exponential growth cells at $28^{\circ} \mathrm{C}$; b- Pre-treatment: exponential phase cells incubated at $40^{\circ} \mathrm{C}$ for $1 \mathrm{~h}$ and immediately transferred to $50^{\circ} \mathrm{C}$ for $8 \mathrm{~min}$; c,f- Heat shock: exponential phase cells incubated directly at $50^{\circ} \mathrm{C}$ for $8 \mathrm{~min}$; d-Values in $10^{8} \mathrm{cfu} \mathrm{ml}^{-1}$; e- Viability of exponential cells first incubated at $28^{\circ} \mathrm{C}$, and then at $40^{\circ} \mathrm{C}$ for $1 \mathrm{~h} ; \mathbf{g}$ - Mean \pm standard error; $\mathbf{h}$ - Survival percentage in relation to no stress control. 
Table 3. Trehalose accumulation and cell viability in Saccharomyces cerevisiae strains isolated from cachaça distilleries after ethanol stress.

\begin{tabular}{ccrrc}
\hline \multirow{2}{*}{ S. cerevisiae strains } & \multicolumn{2}{c}{ Trehalose accumulation $^{\mathrm{a}}$} & \multicolumn{2}{c}{ Cell viability $^{\mathrm{b}}$} \\
\cline { 2 - 5 } & \multicolumn{1}{c}{ Control $^{\mathrm{c}}$} & Ethanol stress $^{\mathrm{d}}$ & \multicolumn{1}{c}{ Control } & Etanol stress $^{\mathrm{f}}$ \\
\hline UFMG-A 1613 & $30.86 \pm 1.23^{\mathrm{e}}$ & $26.0 \pm 2.26$ & $22.60 \pm 0.50$ & $0.04 \pm 0.00(0.15)^{\mathrm{f}}$ \\
UFMG-A 1441 & $39.35 \pm 0.57$ & $31.83 \pm 0.61$ & $280.00 \pm 1.01$ & $1.50 \pm 0.03(0.5)$ \\
UFMG-A 1671 & $28.24 \pm 0.75$ & $17.35 \pm 1.27$ & $2.00 \pm 0.00$ & $0.03 \pm 0.00(1.4)$ \\
UFMG-A 1681 & $44.75 \pm 0.35$ & $18.51 \pm 0.27$ & $4.91 \pm 0.12$ & $0.43 \pm 0.01(8.7)$ \\
UFMG-A 1695 & $40.68 \pm 1.80$ & $23.64 \pm 3.69$ & $39.01 \pm 1.35$ & $0.03 \pm 0.00(0.07)$ \\
UFMG-A 1701 & $14.93 \pm 1.40$ & $9.60 \pm 1.53$ & $0.50 \pm 0.00$ & $<10^{5}(<0.2)$ \\
\hline
\end{tabular}

a- $\mu \mathrm{mol}$ glucose/g wet weight; b- Values in $10^{8} \mathrm{cfu} \mathrm{ml}^{-1} ; \mathbf{c}$ - Cells in stationary phase; d-Cells mantained for $24 \mathrm{hs}$ in $10 \%$ ethanol; e- Mean \pm standard error; $\mathbf{f}$ - Survival percentage in relation to no stress control.

survival under thermal stress conditions observed in our studies may play an important role in the predominance of certain strains the fermentation processes. During cachaça fermentation the temperarture can reach $42^{\circ} \mathrm{C}$ inside the vats, making this environment selective to yeasts that possess good survival mechanisms under these conditions.

The intracellular trehalose content decreased after an ethanol stress in all of the strains tested (Table 3). Strain UFMG97-A1681 had the highest capacity to accumulate trehalose and the greater cell viability after ethanol addition. This strain showed a trehalose decrease of approximately $60 \%$ after the stress. This yeast was probably able to mobilize the intracelular trehalose to protect its proteins, leading to a greater cell viability (21). At the end of the fermentative cycle, the fermented sugar cane juice must reach an ethanol concentration near 7\% (14), such that the strains with a higher trehalose accumulation capacity may have a greater survival probability in this environment.

The high adaptation capacity demonstrated by the yeasts isolated from the fermentation enviroment, and the strong relationship between the trehalose accumulation and the cell viability indicate that this could be one of the mecanisms involved in the survival and predominance of the strains in the fermentation vats. This environment may be a source of yeasts that are potentially useful for the biothechnological applications in the production of food and beverages.

\section{ACKNOWLEDGMENTS}

We are grateful for financial support from Fundação de Amparo à Pesquisa de Minas Gerais (FAPEMIG), Conselho Nacional de Desenvolvimento Científico e Tecnológico (CNPq), and PADCT (process number 62.0477/98-9). We thank the cachaça producers João Paulo Araújo, Acácio de Paula and Walter Caetano for allowing us to use their plant facilities, and Dr. Marc-André Lachance's suggestions to improve the manuscript.

\section{RESUMO}

\section{Acúmulo de trealose, atividade invertásica e características fisiológicas de leveduras isoladas do ciclo fermentativo de 24 horas durante a produção de cachaça artesanal brasileira}

As características fisiológicas, acúmulo de trealose e produção de invertase de 86 leveduras isoladas do ciclo fermentativo durante a produção artesanal de cachaça em três destilarias no Estado de Minas Gerais foram estudadas. Destes isolados $70 \%$ foram capazes de crescer acima de 40 e $42^{\circ} \mathrm{C}$. Somente os isolados de Saccharomyces cerevisiae foram capazes de crescer acima de $40^{\circ} \mathrm{C}$. Baixas temperaturas $\left(<40^{\circ} \mathrm{C}\right)$ favoreceram o crescimento de leveduras como Candida parapsilosis-like, C. maltosa-like, Kloeckera japonica, S. exiguus and $C$. bombicola-like. Os isolados das três destilarias foram tolerantes ao etanol, produziram invertase e acumularam trealose na presença de glicose. As linhagens isoladas da destilaria A apresentaram maior resistência ao etanol (cerca de 84.2\% das linhagens foram capazes de crescer na presença de $12 \%$ de etanol) quando comparadas àquelas das destilarias $\mathrm{B} e$ $\mathrm{C}$ (nenhuma linhagem e 9,5\%, respectivamente). As linhagens de S. cerevisiae isoladas das três destilarias apresentaram uma alta capacidade para produzir invertase e acumular trealose na presença de glicose. Com base nos resultados dos experimentos de estresse térmico e de etanol, foi possível observar uma forte relação entre acúmulo de trealose intracelular e viabilidade celular. $\mathrm{O}$ aumento da viabilidade celular foi mais pronunciado quando as linhagens foram submetidas a um pré-tratamento em temperaturas sub-letais

Palavras-chave: Saccharomyces cerevisiae, cachaça, trealose, invertase, fermentação. 


\section{REFERENCES}

1. Banat, I.M.; Nigam, P.; Singh, D.; Marchant, R.; McHale, A.P. Ethanol production at elevated temperatures and alcohol concentrations: Part 1 - yeasts in general. World J. Microbiol. Biotech., 14: 809-821, 1998.

2. Barnett, J.A.; Payne, R.W.; Yarrow, D. Yeasts: Characteristics and identification. Cambridge University Press, Cambridge, 1980.

3. Corrêa, S.R. Microhabitats ocupados por Saccharomyces cerevisiae durante os períodos de entressafra e produção em três destilarias de aguardente artesanal. Belo Horizonte, 1999, 74p. (Dissertação de Mestrado Instituto de Ciências Biológicas, Depto. Microbiologia da UFMG).

4. D'Amore, T.; Crumplen, R.; Stewart G.G. The involvement of threalose in yeast stress tolerance. J. Ind. Microbiol. 7: 191-196, 1991.

5. Ekunsanmi, T.J.; Odunfa, S.A. Ethanol tolerance, sugar tolerance and invertase activities of some yeast strains isolated from steep water of fermenting cassava tubers. J. Appl. Bacteriol., 69: 672$675,1990$.

6. Hottiger, T.; Schmutz, P.; Wiemken, A. Heat induced accumulation and futile cycling of trehalose in Saccharomyces cerevisiae. J. Bacteriol., 169: 5518-5522, 1987.

7. Hugget, A.S.G.; Nixon, P.A. Enzimic determination of blood glucose. Biochem. J. 66: 12-15, 1957.

8. Kreger-van Rij, N.J.W. The yeasts: a taxonomic study. Elsevier Science Publishers BV, Amsterdam, 1984.

9. Kurtzman, C.P.; Fell, J.W. The yeast: a Taxonomic Study. Amsterdam: Elsevier Science Plublisher, 1998.

10. Lachance, M.A. Yeast communities in a natural tequila fermentation. Antonie van Leeuweehoek, 68: 151-160, 1995.

11. Lewis, J.G.; Learmonth, R.P.; Watson, K. Induction of heat, freezing and salt tolerance by heat and shock in Saccharomyces cerevisiae. Microbiology, 141: 687-694, 1995.

12. Mansure, J.J.C.; Panek, A.D.; Crowe, L.M.; Crowe, J.H. Trehalose inhibits ethanol effects on intact yeast cells and liposomes. Bioch. Bioph. Acta, 1191: 309-316, 1994.

13. Morais, P.B.; Rosa, C.A.; Linardi, V.R.; Carazza, F.; Nonato, E.A. Production of fuel alcohol by Saccharomyces strains from tropical habitats. Biotech. Lett., 18: 1351-1356, 1996.
14. Morais, P.B.; Rosa, C.A.; Linardi, V.R.; Pataro, C.; Maia, A.B.R.A. Characterization and sucession of yeast populations associated with spontaneous fermentation during the production of the brazilian sugar-cane "aguardente". World J. Microbiol. Biotechn., 13: 241243, 1997.

15. Neves, M..J.; François, J. On the mechanism by which a heat shock induces trehalose accumulation in Saccharomyces cerevisiae. Biochem. J., 288: 859-864, 1992.

16. Neves, M.J.; Terenzi, H.F.; Leone, F.A.; Jorge, J.A. Quantification of trehalose in biological samples with a conodial trehalase from the thermophilic fungus Humicola grisea var. thermoidea. World. J. Microbiol. Biotech., 10: 17-19, 1994

17. Pataro, C.; Santos, A.; Corrêa, S.R.; Morais, P.B.; Linardi, V.R.; Rosa, C.A. Physiological characterization of yeasts isolated from artisanal fermentation in an aguardente distillery. Rev. Microbiol., 29:104-108, 1998.

18. Pataro, C.; Guerra, J. B.; Petrillo-Peixoto, M.L.; Mendonça-Hagler, L.C.; Linardi, V.R.; Rosa, C.A. Yeast communities and genetic polymorphism of Saccharomyces cerevisiae strains associated with artisanal fermentations in Brazil. J. Appl. Microbiol., 89: 24-31, 2000.

19. Ribeiro, M.J.S.; Leão, L.S.C.; Morais, P.B.; Rosa, C.A.; Panek, A.D. Trehalose accumulation by tropical yeast strains submitted to stress conditions. Antonie van Leeuwenhoek, 75: 245-251, 1999.

20. Ribeiro, M.J.S.; Silva, J.T.; Panek, A.D. Trehalose metabolism in Saccharomyces cerevisiae during heat-shock. Bioch. Bioph. Acta, 1200: 139-147, 1994.

21. Singer, M.A.; Lindquist, S. Thermotolerance in Saccharomyces cerevisiae: the Yin and Yang of trehalose. Tibtech, 16: 460-468, 1998.

22. Soto, T.; Fernandez, J.; Vicente-Soler, J.; Cansado, J.; Gacto, M. Accumulation of Trehalose by overexpression of tps 1, coding for trehalose-6-phosphate synthase, causes increased resistance to multiple stresses in the fission yeasts Schizosaccharomyces pombe. Appl. Environ. Microbiol., 65: 2020-2024, 1999.

23. van der Walt, J.P.; Yarrow, D. Methods for the isolation, maintenance, classification and identification of yeasts. In: The yeasts: a taxonomic study. Elsevier Publishers BV, Amsterdam. 1984. pp.45-104.

24. Van Dijck, P.; Colavizza, D.; Smet, P.; Thevelein, J.M. Differential importance of trehalose in stress resistance in fermenting and nonfermenting Saccharomyces cerevisiae cells. Appl. Environ. Microbiol., 61: 109-115, 1995. 